\title{
Menstruation in short-tailed fruit bats (Carollia spp.)
}

\author{
J. J. Rasweiler IV ${ }^{1}$ and H. de Bonilla ${ }^{2}$ \\ ${ }^{1}$ Department of Obstetrics and Gynecology, Cornell University Medical College, 1300 York Avenue, \\ New' York, NY 10021, USA; and '2 Departamento de Biologia, Facultad de Ciencias, \\ Universidad Nacional de Colombia, Bogota, Colombia
}

\begin{abstract}
Summary. Uterine function was assessed histologically in Carollia spp. removed from a laboratory breeding colony. The uteri of periovulatory bats examined on days 1-3 post coitum varied considerably depending upon whether regressing corpora lutea were present. In females lacking such corpora lutea, the endometrium was shallow and proliferative. In most of the bats having regressing corpora lutea, the endometrium was thicker and necrotic portions of the superficial lamina functionalis were being sloughed off with associated bleeding (i.e. in the form of a true menstrual process). The presence of regressing corpora lutea and well-developed endometria in these animals indicated that short-tailed fruit bats are spontaneous ovulators with a functional luteal phase to their cycles. Menstruation was also observed in some females that were not periovulatory, or that lacked regressing corpora lutea. The endometrium was not vascularized by spiral arterioles, but it did contain distinctive granulocytes similar to those observed in catarrhine primates and other menstruating bats. Most endometrial growth occurred after ovulation and, in pregnant animals, was associated with retention of the embryos in the oviducts for approximately 13-16 days. Carollia perspicillata normally produces one young at a time, after a gestation period of about 4 months, and is a seasonal breeder in the wild. Menstruation probably provides this bat with an efficient mechanism for eliminating a well-developed endometrium from its simplex uterus in the event of fertilization failure or early embryonic loss. This may give the female another chance to establish a pregnancy and produce an infant at a reasonably opportune time during the same breeding season.
\end{abstract}

Kelwords: fruit bat; menstruation; reproductive cycle; uterus; Carollia

\section{Introduction}

Short-tailed fruit bats of the genus Carollia occur from southern Mexico to Bolivia, Paraguay and south-eastern Brazil, and are among the most common neotropical mammals (Pine, 1972; Handley, 1976). These bats feed on fruit, floral components and insects (Sazima, 1976; Gardner, 1977; Rasweiler, 1977a; Fleming, 1988). Carollia spp. are important ecologically because of the roles they play in pollinating and disseminating the seeds of some tropical plants (Fleming, 1988).

Work with a closely related phyllostomid bat, Glossophaga soricina, has established that this species is interesting for studies of uterine biology, implantation and placentation because it exhibits many similarities to humans. Among these are a simplex uterus, true menstruation and the possession of distinctive uterine granulocytes of uncertain function (Hamlett, 1934; Rasweiler, $1972,1979 \mathrm{a}, \mathrm{b})$. Implantation of the single blastocyst in $G$. soricina is interstitial and is restricted to a highly localized, predetermined site in the uterine fundus (Rasweiler, 1974, 1979a). Implantation in humans is not so restricted, but does occur preferentially on the dorsal or ventral uterine wall, in line with the midsagittal plane of the uterus (Mossman, 1937, 1987). Both of these species 
possess highly invasive trophoblast, exhibit pronounced decidual reactions and develop discoidal haemochorial placentas (Hamlett, 1935; Rasweiler, 1974).

Comparative studies of Carollia were initiated as part of an effort to determine how widespread the reproductive characteristics exhibited by $G$. soricina are in the large and highly diversified family Phyllostomidae, because (i) the abundance of Carollia spp. would facilitate their possible development as new experimental models, (ii) the larger body of Carollia spp. would be an advantage in reproductive endocrine studies, and (iii) the ecological importance of the species. Previous reports have dealt with breeding activity, some aspects of ovarian function, early embryonic development, oviductal cytology and the development of a unilateral oviductal reaction in Carollia (Bonilla \& Rasweiler, 1974; Rasweiler, 1979a). This paper focuses on the occurrence of menstruation in these bats.

\section{Materials and Methods}

\section{Animal procurement}

All the animals used in this study were captured with hand or mist nets in the Western Andean Cordillera near Cali, Colombia.

\section{Species identification}

While maintained and bred in the laboratory, all the bats were treated as one species, Carollia perspicillata (Rasweiler \& Bonilla, 1972). As differentiation of some of the species of Carollia was a problem at this time (Fleming et al., 1972; Gardner, 1977), skulls were saved from animals in the laboratory colony. Upon comparing these with characteristics reported in a taxonomic revision of the genus Carollia, which appeared after the study of live animals was completed (Pine, 1972), it became apparent that two species, C. perspicillata and C. brevicauda, were probably present (Bonilla \& Rasweiler, 1974).

\section{Animal care and management}

The bats were maintained in a laboratory colony established at the Universidad del Valle in Cali, Colombia, using methods described previously (Rasweiler \& Bonilla, 1972). The animals were housed in a room with a controlled light cycle ( $13 \mathrm{~h}$ light: $11 \mathrm{~h}$ dark) and a temperature of $21-28^{\circ} \mathrm{C}$. They were fed a fruit-based liquid diet each night. As the initial aim of this study was to examine early embryonic development, the females were caged in sexually segregated groups of 15-20 bats for 3-8 months before the initiation of efforts to breed them. Two or three males were then placed with each group of females. Some of the mated females were subsequently found to be menstruating.

\section{Timing of reproductive stages}

Smears were obtained from the females each morning between $07: 00$ and 10:00 h by aspirating a small amount of distilled water in the vagina with a microeyedropper (described in Rasweiler, 1987). The first day on which spermatozoa were found in a smear was considered to be day 1 post coitum (p.c.).

\section{Histological procedures}

All the bats were killed between 08:00 and 10:00 h at various intervals after the onset of mating and their reproductive tracts were removed for histological examination. Most of the reproductive tracts were fixed in Zenker's fiuid for $8 \mathrm{~h}$, washed overnight in running tap water and processed through graded ethyl alcohols, cedar wood oil and benzene to paraffin wax. A small series was fixed in cold $\left(4^{\circ} \mathrm{C}\right)$ Carnoy's fluid for $8 \mathrm{~h}$ and processing to paraffin was started in $100 \%$ ethanol. The tracts were then serially sectioned at $7 \mu \mathrm{m}$ in a frontal plane. The Zenker-fixed material was stained with haematoxylin and eosin, haematoxylin and buffered Giemsa (pH 4.5), or Masson's trichrome procedure. The Carnoy-fixed tracts were stained with haematoxylin and one of the following: eosin, the periodic acid-Schiff (PAS) procedure, or PAS-Alcian blue 8GX (Bonilla \& Rasweiler, 1974).

\section{Uterine measurements}

The thickness of the endometrium was measured on the medial or lateral walls of the proximal portion of the uterine corpus. Mitotic activity in the glandular epithelium and the endometrial stroma, as well as endometrial 
stromal cell density, were measured in the proximal portion of the uterine corpus including the fundus. Mitotic activity in the glandular epithelium was determined by examining 500 cells from each uterus. During days 1-6 p.c., all portions of the glands were included. As mitotic activity then generally disappeared from the deepest portions of the glands, the number of cells undergoing mitosis was counted only on the upper three-quarters of the glands on days 7-8 p.c., the upper two-thirds of the glands on days 9-11 p.c. and the upper two-thirds to half of the glands on days 12-16 p.c. The number of stromal cells undergoing mitosis was counted in ten randomly selected fields $\left(62 \mu \mathrm{m}^{2}\right)$ in the lamina functionalis. Stromal cell density was measured in five randomly selected fields $\left(62 \mu \mathrm{m}^{2}\right)$ in the lamina functionalis.

\section{Statistical analyses}

Differences between mean values for endometrial variables measured in bats in various physiological states were tested for significance by Student's $t$ test. Data from one animal with a clearly abnormal (hyperplastic) uterus examined on day 1 p.c. were omitted from the analyses.

\section{Results}

\section{General reproductive condition}

Most of the mated females were found, upon histological examination, to possess large preovulatory follicles ( $n=5$ bats), to carry newly ovulated, unfertilized ova ( $n=4$ bats), or to be in early pregnancy ( $n=60$ bats). There were also 38 mated females that were not pregnant. Some of these $(n=14)$ lacked preovulatory follicles or corpora lutea. Others $(n=24)$ possesssed corpora lutea, but their tracts did not always appear to be synchronized properly in accordance with expected histological appearance for the post-coital day. This is because, in Carollia, as in some other bats, female receptivity is not always restricted to the periovulatory period (Rasweiler, 1987).

\section{Uterine histology}

The uteri of periovulatory females killed on days 1-3 p.c. varied considerably in histological appearance depending upon whether regressing corpora lutea were present (Table 1; Figs 1-2). In the bats lacking regressing corpora lutea, the endometrium was quite shallow (Figs 3, 4a), but mitotic activity was evident in the glands and stroma. Particularly high mitotic activity was evident in the endometrial glands of two such animals possessing large Graafian follicles. In most of the bats having regressing corpora lutea, the endometrium was thicker (Figs $4 b-5 b$ ). Portions of the superficial lamina functionalis in these animals were frequently necrotic and in the process of being sloughed off with associated bleeding, i.e. in the form of a true menstrual process. None of the menstruating or post-menstrual animals were observed with large amounts of necrotic endometrial tissue in the uterine lumina, or with just the lamina basalis of the endometrium remaining. A considerable amount of the lamina functionalis appeared to be retained from one uterine cycle into the next. Unfortunately, it was impossible to quantify this with precision, because the lamina functionalis could not be sharply delineated from the lamina basalis. The lutein cells in the regressing corpora lutea were much smaller than those in the presumably functional corpora lutea present immediately before implantation (cf. Figs $5 \mathrm{c}$ and 6).

Most (14 of 15) of the periovulatory females killed on days 1-2 p.c. had spermatozoa in their uteri (Figs 3 and 4a), and, in the menstruating animals, some of these had penetrated into the superficial endometrial stroma. By days 3-4 p.c., few spermatozoa remained in the uteri and often these were restricted to the uterine glands.

Two pregnant females that possessed developing and regressing corpora lutea were examined on days 4-5 p.c. One of these bats was still in the final stages of menstruation, while the other possessed a proliferative endometrium, but blood and necrotic cellular debris were abundant in her uterine cavity.

When the uteri of the menstruating animals (days 1-5 p.c.) were compared with those from the remaining bats, several major differences became evident. Mitotic activity in the epithelial cells of 
Table 1. Reproductive condition of laboratory-bred short-tailed fruit bats (Carollia spp.)

\begin{tabular}{|c|c|c|c|c|c|}
\hline $\begin{array}{l}\text { Day } \\
\text { post coitum }\end{array}$ & $\begin{array}{l}\text { No. of } \\
\text { bats }\end{array}$ & $\begin{array}{l}\text { Stage of development } \\
\text { and location of ovum }\end{array}$ & $\begin{array}{l}\text { Ovarian } \\
\text { condition }\end{array}$ & $\begin{array}{l}\text { Endometrial } \\
\text { condition }\end{array}$ & $\begin{array}{l}\text { Thickness } \\
(\mu \mathrm{m})\end{array}$ \\
\hline 1 & 1 & Preovulatory & Large GF & Proliferative & $100-130^{\mathrm{a}}$ \\
\hline 1 & 1 & Preovulatory & Large GF & Proliferative & $300-400$ \\
\hline 1 & 1 & Preovulatory & $\begin{array}{l}\text { Large } G F+ \\
\quad \text { regressing } C L\end{array}$ & $\begin{array}{l}\text { Menstrual } \\
\text { (early) }\end{array}$ & $600-700$ \\
\hline 1 & I & Preovulatory & $\begin{array}{l}\text { Large } G F+ \\
\quad \text { regressing } C L\end{array}$ & $\begin{array}{l}\text { Menstrual } \\
\text { (mid) }\end{array}$ & $300-400$ \\
\hline 1 & 1 & Preovulatory & $\begin{array}{l}\text { Large } \mathrm{GF}+ \\
\quad \text { regressing } \mathrm{CL}\end{array}$ & $\begin{array}{l}\text { Menstrual } \\
\text { (hyperplastic) }\end{array}$ & $900-1800$ \\
\hline I & 1 & $\begin{array}{l}\text { Secondary oocyte in } \\
\text { oviduct }\end{array}$ & Recently RF & Proliferative & $200-250$ \\
\hline 1 & 1 & $\begin{array}{l}\text { Secondary oocyte in } \\
\text { oviduct }\end{array}$ & $\begin{array}{l}\text { Recently } \mathrm{RF}+ \\
\text { regressing } \mathrm{CL}\end{array}$ & $\begin{array}{l}\text { Menstrual } \\
\text { (early) }\end{array}$ & $550-600$ \\
\hline 1 & 1 & $\begin{array}{l}\text { Secondary oocyte in } \\
\text { oviduct }\end{array}$ & $\begin{array}{l}\text { Recently } \mathrm{RF}+ \\
\text { regressing CL }\end{array}$ & $\begin{array}{l}\text { Menstrual } \\
\text { (mid) }\end{array}$ & $575-750$ \\
\hline 1 & 1 & $\begin{array}{l}\text { Secondary oocyte in } \\
\text { oviduct }\end{array}$ & $\begin{array}{l}\text { Recently } \mathrm{RF}+ \\
\text { very old } \mathrm{CL}\end{array}$ & Proliferative & $350-400$ \\
\hline 2 & 1 & $\begin{array}{l}\text { Pronuclear stage ovum } \\
\text { in oviduct }\end{array}$ & Recently RF & Proliferative & $350-450$ \\
\hline 2 & 4 & $\begin{array}{l}\text { Pronuclear stage ovum } \\
\text { in oviduct }\end{array}$ & $\begin{array}{l}\text { Developing } C L+ \\
\text { regressing } C L\end{array}$ & $\begin{array}{l}\text { Menstrual } \\
\quad \text { (early to late) }\end{array}$ & $350-650$ \\
\hline 2 & 1 & $\begin{array}{l}\text { Pronuclear stage ovum } \\
\text { in oviduct }\end{array}$ & $\begin{array}{l}\text { Developing } C L+ \\
\text { regressing CL }\end{array}$ & $\begin{array}{l}\text { Menstrual (late) } \\
\text { to proliferative }\end{array}$ & $550-650$ \\
\hline 3 & 2 & $\begin{array}{l}\text { Pronuclear stage ovum } \\
\text { in oviduct }\end{array}$ & $\begin{array}{c}\text { Developing CL }+ \\
\text { regressing CL }\end{array}$ & $\begin{array}{l}\text { Menstrual } \\
\text { (early) }\end{array}$ & $600-700$ \\
\hline 3 & 1 & $\begin{array}{l}2 \text {-cell embryo in } \\
\text { oviduct }\end{array}$ & Developing CL & Proliferative & $400-450^{b}$ \\
\hline 4 & 1 & $\begin{array}{l}\text { 8-cell embryo in } \\
\text { oviduct }\end{array}$ & $\begin{array}{l}\text { Developing } \mathrm{CL}+ \\
\text { regressing CL }\end{array}$ & Proliferative & $400-500$ \\
\hline 4 & l & $\begin{array}{l}\text { 8-cell embryo in } \\
\text { oviduct }\end{array}$ & Developing CL & Menstrual & $400-450$ \\
\hline 5 & 1 & $\begin{array}{l}\text { 8-cell embryo in } \\
\text { oviduct }\end{array}$ & $\begin{array}{l}\text { Developing } \mathrm{CL}+ \\
\text { regressing } \mathrm{CL}\end{array}$ & $\begin{array}{l}\text { Menstrual } \\
\text { (late) }\end{array}$ & $350-500$ \\
\hline 6 & 1 & $\begin{array}{l}\text { 14-cell morula in } \\
\text { oviduct }\end{array}$ & Developing CL & Proliferative & $300-525$ \\
\hline 7 & 1 & $\begin{array}{l}\text { 15-cell morula in } \\
\text { oviduct }\end{array}$ & New $C L+$ regressing $C L$ & Proliferative & $375-500$ \\
\hline 8 & 2 & $\begin{array}{l}19-26 \text { cell morula in } \\
\text { oviduct }\end{array}$ & New $\mathrm{CL}+$ regressing $\mathrm{CL}$ & Proliferative & $525-900$ \\
\hline 9 & 1 & $\begin{array}{l}\text { 18-cell morula in } \\
\text { oviduct }\end{array}$ & New CL & Proliferative & $475-625$ \\
\hline 9 & 1 & $\begin{array}{l}\text { 73-cell morula in } \\
\text { oviduct }\end{array}$ & New CL & Proliferative & $600-775$ \\
\hline 10 & 1 & $\begin{array}{l}\text { 42-cell morula in } \\
\text { oviduct }\end{array}$ & New CL & Proliferative & $425-625$ \\
\hline 10 & 1 & $\begin{array}{l}\text { 88-cell morula in } \\
\text { oviduct }\end{array}$ & New $C L+$ regressing $C L$ & Proliferative & $525-725$ \\
\hline 10 & 1 & $\begin{array}{l}\text { Blastocyst }(-Z P) \text { in } \\
\text { oviduct }\end{array}$ & New $C L+$ regressing $C L$ & Proliferative & $500 \quad 650$ \\
\hline 11 & 1 & $\begin{array}{l}\text { 82-cell morula in } \\
\text { oviduct }\end{array}$ & New CL & Proliferative & $775-825$ \\
\hline 11 & 1 & $\begin{array}{l}\text { Blastocyst }(-Z P) \text { in } \\
\text { oviduct }\end{array}$ & New CL & Proliferative & $600-800$ \\
\hline 12 & 1 & $\begin{array}{l}100 \text {-cell morula in } \\
\text { oviduct }\end{array}$ & New CL & Proliferative & $575-625$ \\
\hline 12 & 2 & $\begin{array}{l}\text { Blastocyst }(+Z P) \text { in } \\
\text { oviduct }\end{array}$ & $\begin{array}{l}\text { New } C L+\text { regressing } C L \\
\quad(1 \text { bat })\end{array}$ & Proliferative & $600-800$ \\
\hline
\end{tabular}


Table 1. Continued

\begin{tabular}{|c|c|c|c|c|c|}
\hline $\begin{array}{c}\text { Day } \\
\text { post coitum }\end{array}$ & $\begin{array}{l}\text { No. of } \\
\text { bats }\end{array}$ & $\begin{array}{l}\text { Stage of development } \\
\text { and location of ovum }\end{array}$ & $\begin{array}{l}\text { Ovarian } \\
\text { condition }\end{array}$ & $\begin{array}{l}\text { Endometrial } \\
\text { condition }\end{array}$ & $\begin{array}{l}\text { Thickness } \\
(\mu \mathrm{m})\end{array}$ \\
\hline 13 & 2 & $\begin{array}{l}\text { Blastocyst }(-\mathrm{ZP}) \text { in } \\
\text { oviduct }\end{array}$ & New CL & Proliferative & $550-725$ \\
\hline 14 & 1 & $\begin{array}{l}\text { Blastocyst }(-\mathrm{ZP}) \text { in } \\
\text { oviduct }\end{array}$ & New $\mathrm{CL}+$ regressing $\mathrm{CL}$ & Proliferative & $575-700$ \\
\hline 14 & 2 & $\begin{array}{l}\text { Blastocyst }(-Z P) \text { in } \\
\text { uterus }\end{array}$ & $\begin{array}{l}\text { New } C L+\text { regressing } C L \\
\text { (I bat) }\end{array}$ & Proliferative & $550-975$ \\
\hline 15 & 1 & $\begin{array}{l}\text { Blastocyst }(-\mathrm{ZP}) \text { in } \\
\text { oviduct }\end{array}$ & New $C L$ & Proliferative & $675-875$ \\
\hline 15 & 3 & $\begin{array}{l}\text { Blastocyst }(-\mathrm{ZP}) \text { in } \\
\text { uterus }\end{array}$ & $\begin{array}{l}\text { New } C L+\text { regressing } C L \\
\text { (2 bats) }\end{array}$ & Proliferative & $675-975$ \\
\hline 16 & 1 & $\begin{array}{l}\text { Blastocyst }(-Z P) \text { in } \\
\text { oviduct }\end{array}$ & New CL & Proliferative & $525-675$ \\
\hline
\end{tabular}

GF, Graafian follicle; RF, ruptured follicle; +ZP, zona pellucida present; -ZP, no zona pellucida was present around blastocyst.

${ }^{2}$ Endometrial thickness was reduced because of dilatation of the uterus with fluid.

${ }^{\mathrm{b}} \mathrm{Abundant}$ blood and a filarial nematode were present in the uterine cavity.

(a)
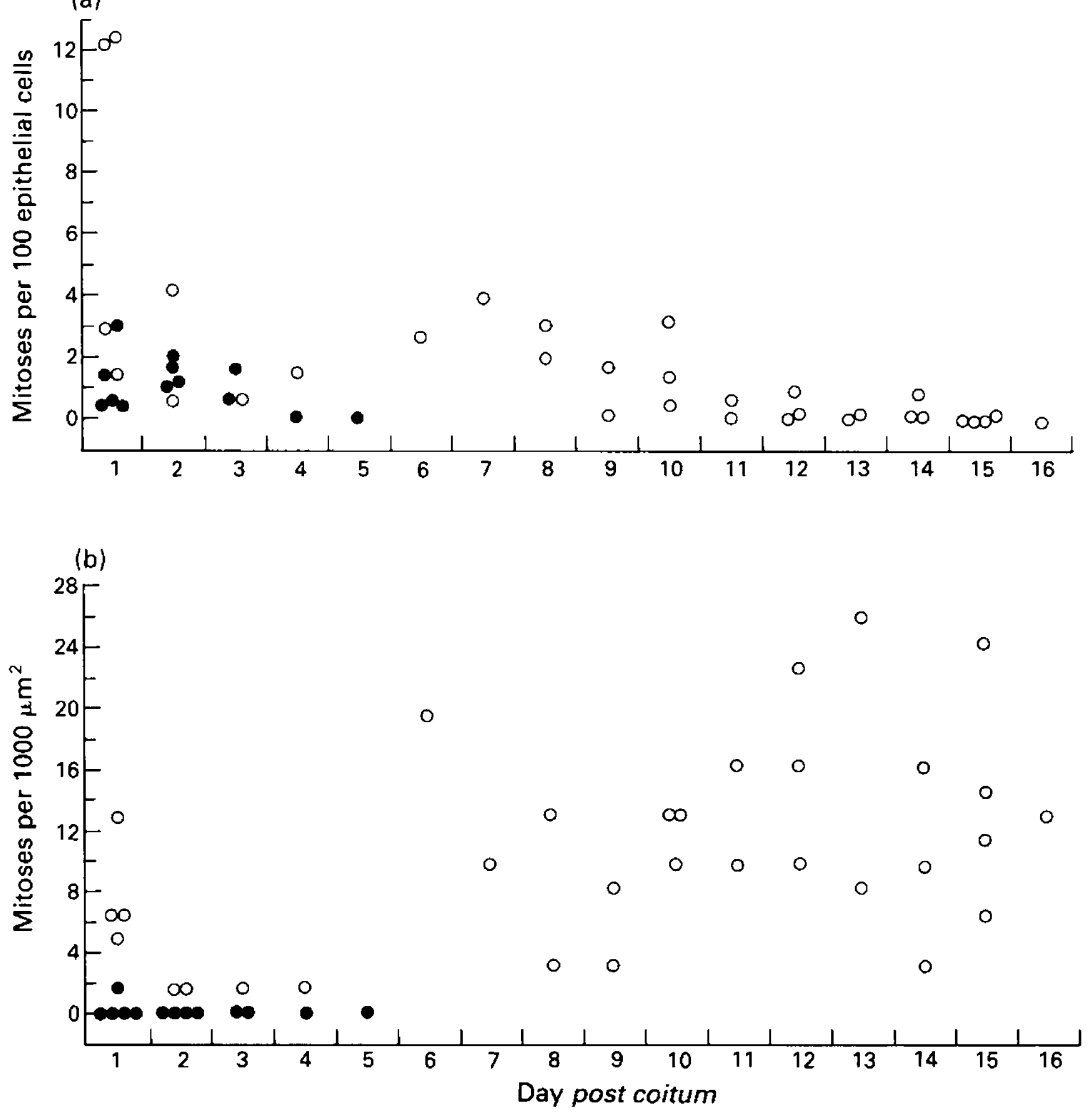

Fig. 1. Mitotic activity in (a) the endometrial glands and (b) the stroma of the endometrial lamina functionalis of laboratory-bred short-tailed fruit bats (Carollia spp.); animals with menstrual uteri $(\bullet)$ and with nonmenstrual uteri $(O)$. 


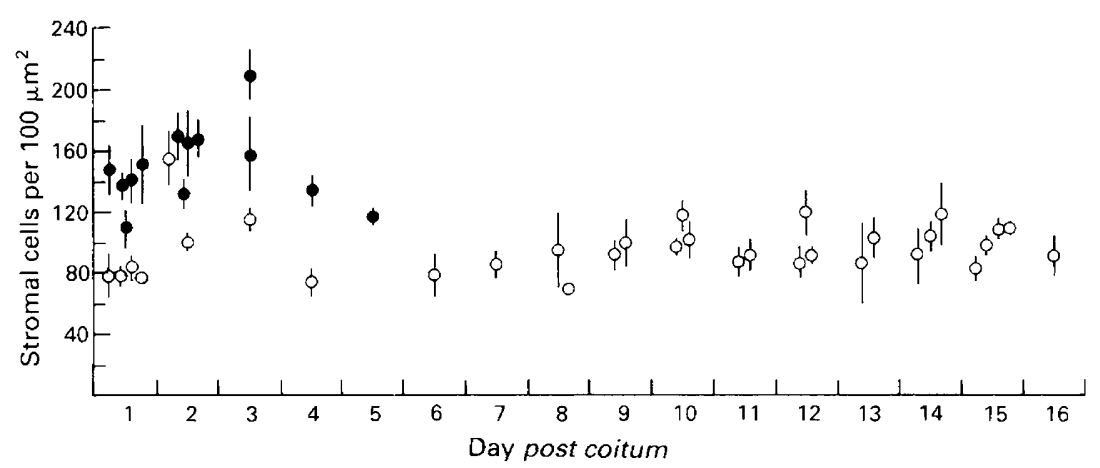

Fig. 2. Stromal cell density (mean $\pm S D$ ) in the endometrial lamina functionalis of laboratory-bred short-tailed fruit bats. Animals with menstrual uteri $(\bullet)$ and nonmenstrual uteri $(O)$.

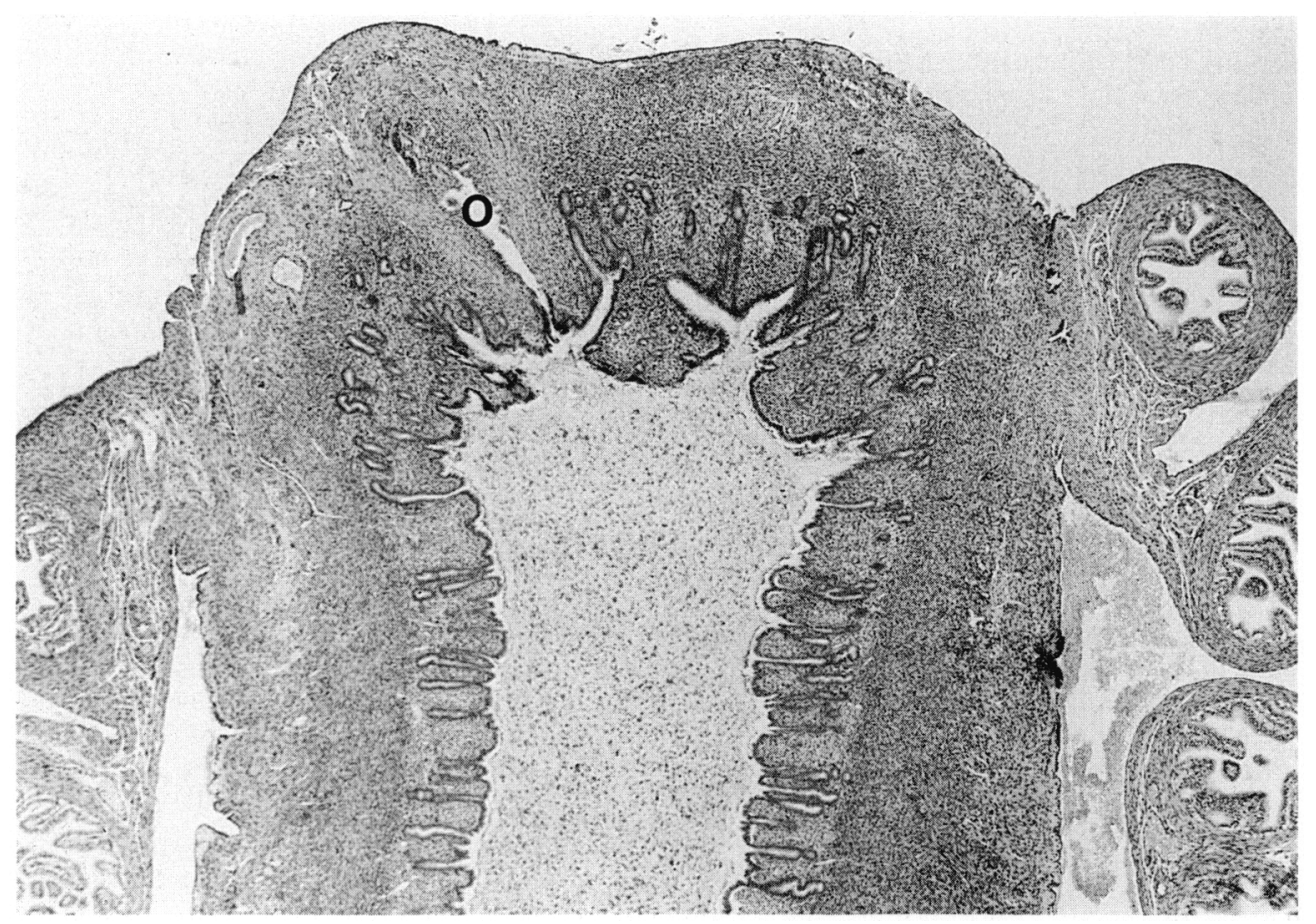

Fig. 3. Uterus from a female examined on day 1 post coitum. This animal had a newly ruptured follicle, but no old corpus luteum, and carried an oviductal, secondary oocyte. The endometrium was shallow and proliferative. Large numbers of spermatozoa were present in the lumen. $\mathrm{O}$ : intramural portion of the oviduct. Haematoxylin and eosin, $\times 21$.

the endometrial glands (Fig. 1a) was significantly less in the menstrual uteri than in the proliferative uteri examined on days $1-4$ p.c. $(P<0.025)$ or days $6-10$ p.c. $(P<0.001)$. Mitotic activity in the stromal cells of the lamina functionalis (Fig. 1b) was nearly absent and significantly less in the menstrual uteri than in the proliferative uteri examined on days $1-3$ p.c. $(P<0.005)$ or days 6-16 p.c. $(P<0.001)$. Finally, the stromal cell density in intact portions of the lamina functionalis (Fig. 2) was significantly greater $(P<0.001)$ in the menstrual uteri than in the proliferative uteri examined on days $1-16$ p.c. 
(a)

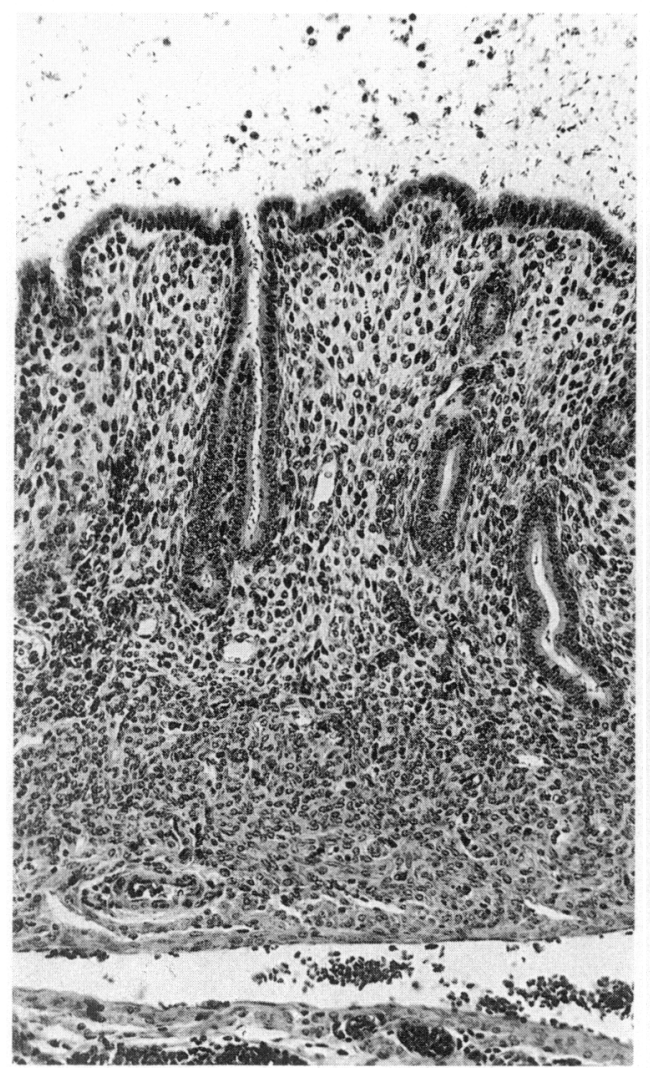

(b)

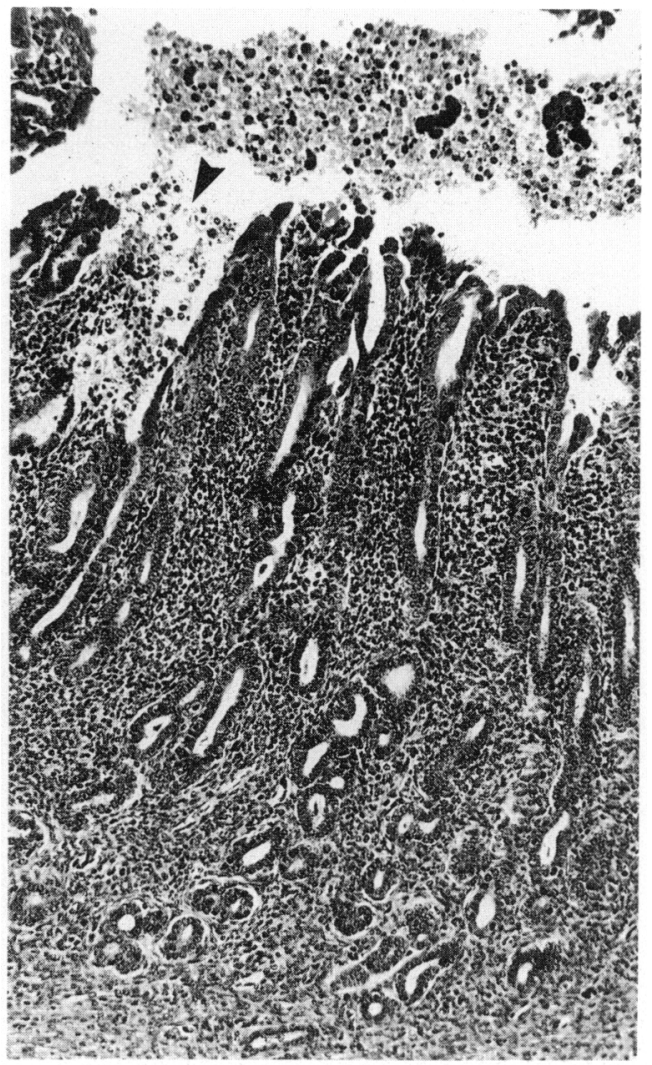

Fig. 4. (a) Shallow, proliferative endometrium from a female examined on day 1 post coitum. This animal had a large Graffian follicle, but no old corpus luteum. Masson's trichrome, $\times 141$. (b) Early menstrual endometrium from a female examined on day 3 post coitum. This animal had a newly ruptured follicle, a regressing corpus luteum, and carried an oviductal, pronuclear stage ovum. The endometrium was thick, with a densely cellular stroma and some necrotic foci (c.g. at arrowhead). Desquamated endometrial tissue and blood were present in the lumen. Masson's trichrome, $\times 141$.

Menstruation was also observed in some atypical, mated females. One was a nonpregnant bat with growing vesicular follicles and a corpus albicans, but no reasonably intact corpus luteum. This animal exhibited a preovulatory, unilateral oviductal reaction (Bonilla \& Rasweiler, 1974). Her endometrium was shallow $(225-300 \mu \mathrm{m})$, but had a compact, densely cellular stroma. Substantial mitotic activity was evident in the endometrial glands. Another menstruating female, examined on day 4 p.c., lacked any evidence of a regressing corpus luteum (Fig. 7) and carried an oviductal, eight-cell embryo. Two nonpregnant, menstruating bats lacked Graafian follicles or corpora lutea, but exhibited bilateral infiltration of their ovarian medullae by luteal-like interstitial gland cells (Bonilla \& Rasweiler, 1974). The endometria in both these bats were quite thick $(550-675 \mu \mathrm{m})$. Two menstruating females had regressing corpora lutea, but no large preovulatory follicles or developing corpora lutea; they also did not exhibit any signs of the oviductal stimulation usually associated with advanced follicular development (Bonilla \& Rasweiler, 1974).

Most of the pregnant animals killed between days 6 and 10 p.c. had proliferative endometria with mitotic activity evident in the glandular epithelial cells and the stroma of the lamina functionalis (Fig. 1a, b). Until day 8 p.c., it was common to see necrotic cellular debris of apparent 
(a)

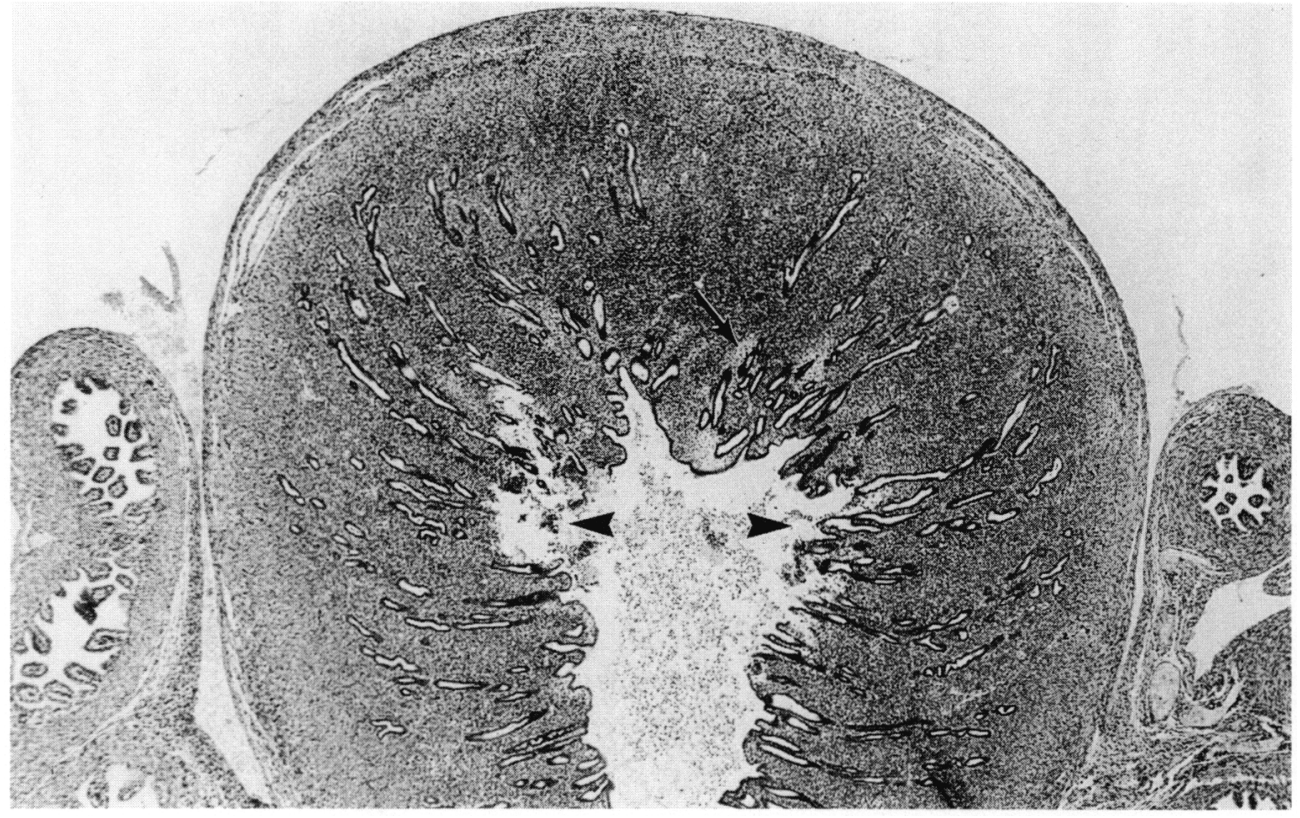

(b)

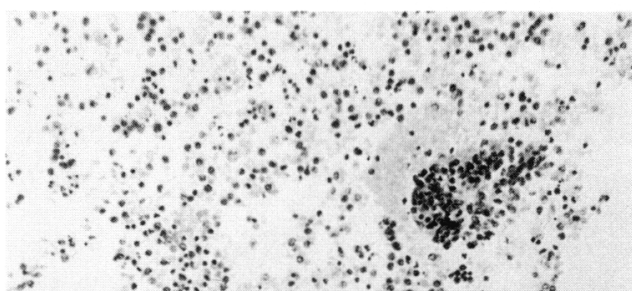

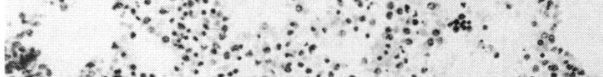

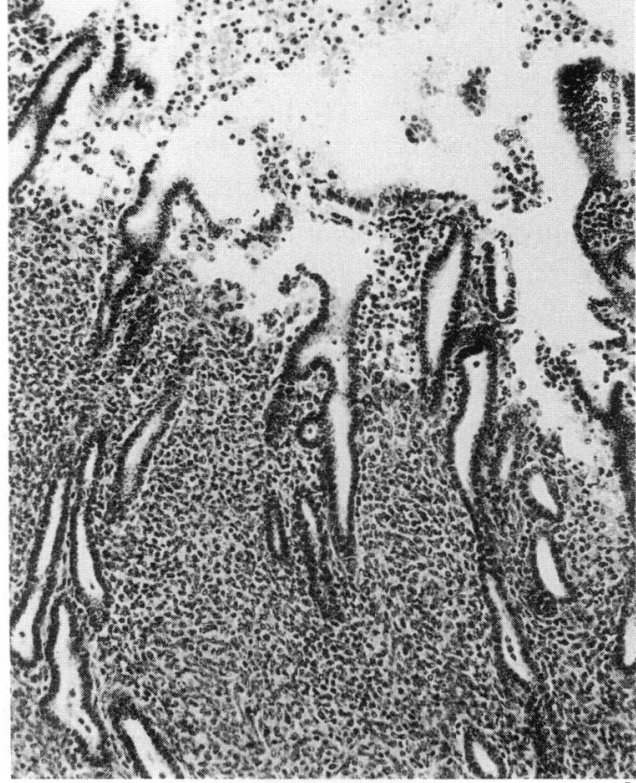

(c)

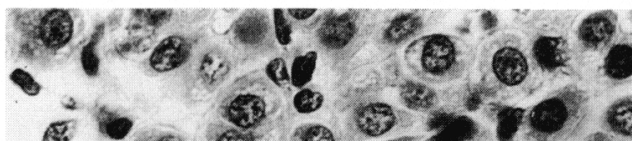

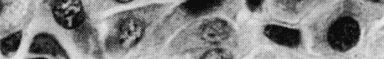

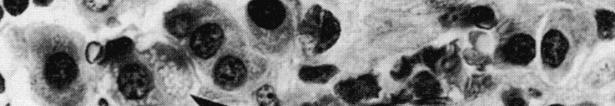

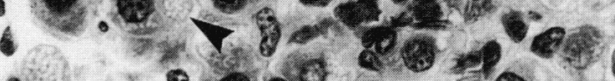
1.9

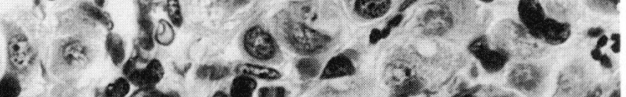

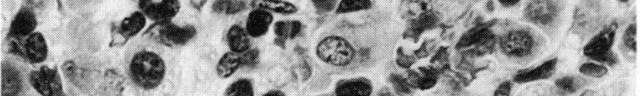

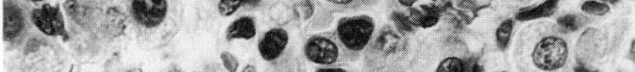

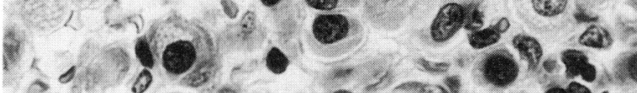

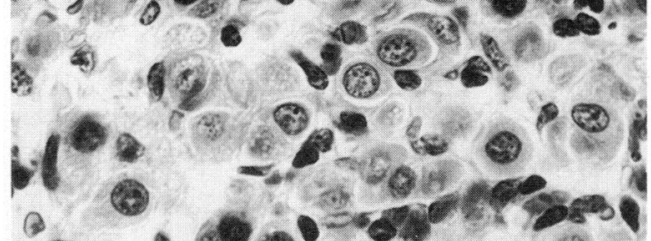

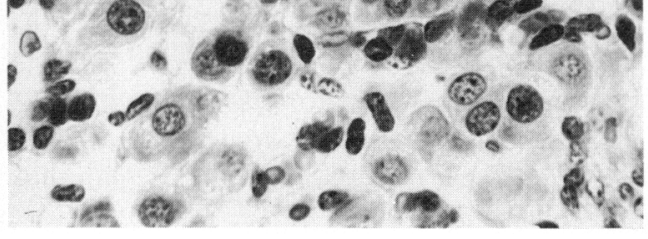




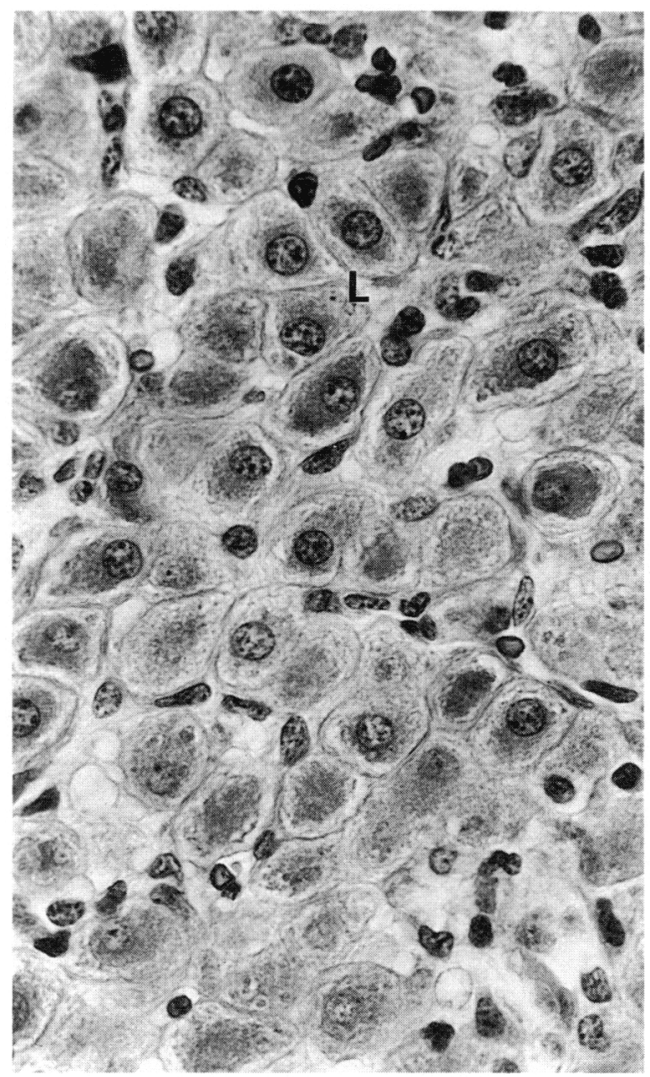

Fig. 6. Portion of a well-developed corpus luteum present in a pregnant female on day 16 post coitum. This animal carried an oviductal, zona-free blastocyst. L: lutein cells. Masson's trichrome, $\times 561$.

menstrual origin (because of the presence of epithelial cells or erythrocytes, or both) in the uterine lumina of the pregnant females with new and regressing corpora lutea. After day 10, mitotic activity in the glandular epithelium (Fig. 1a) was significantly less than in proliferative endometria examined on days $1-10(P<0.05)$. Substantial mitotic activity continued in the endometrial stroma through the initiation of implantation (Fig. 1b). As a result, the endometrium was very thick immediately before implantation (Fig. 8a,b). This was always associated with a well-developed corpus luteum (Fig. 6).

Implanting blastocysts were observed in two of three bats examined on day 16 p.c., all five bats examined on day 17 p.c. and all seven bats examined on day 18 p.c. In the bats with implanting

Fig. 5. (a) Menstrual uterus from a female examined on day 1 post coitum. This animal had a large Graafian follicle and a regressing corpus luteum. Considerable endometrial necrosis and sloughing are evident in two areas (arrowheads). Pale regions within the superficial endometrium (c.g. at arrow) contain necrotic stroma. Haematoxylin and eosin, $\times 21$. (b) Higher power view of a portion of the superficial endometrium and lumen. Haematoxylin and eosin, $\times 141$. (c) Portion of the regressing corpus luteum associated with the menstrual uterus. The lutein cells were smaller than those in corpora lutea examined immediately before implantation (cf., Fig. 6). Also, many of the lutein cells in this corpus luteum contained large numbers of small cytoplasmic vacuoles (e.g. at arrowhead). Masson's trichrome, $\times 561$. 


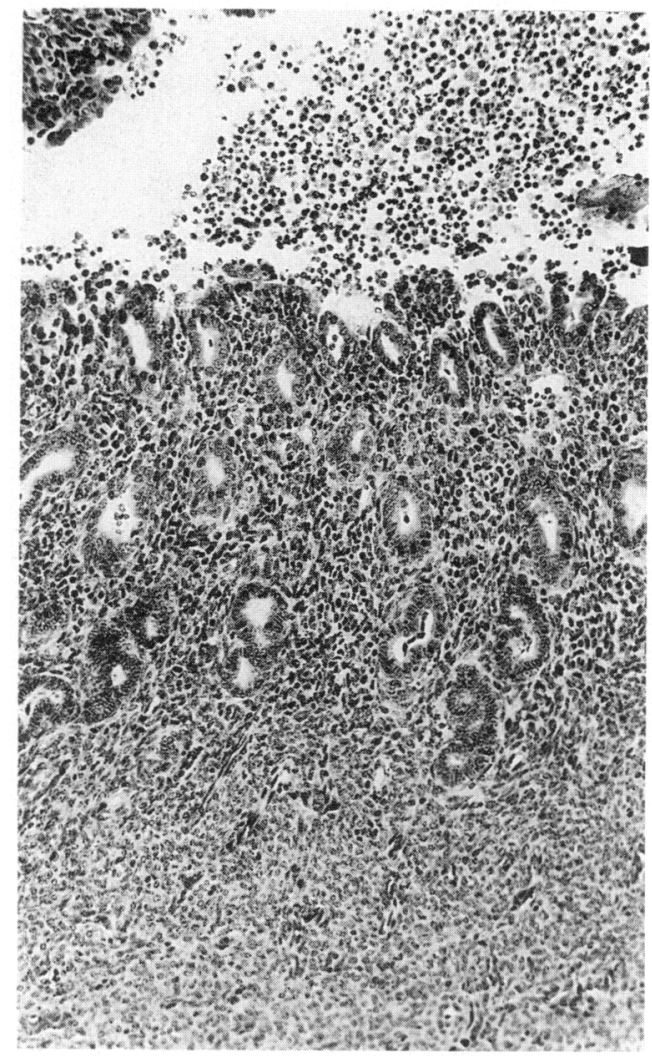

Fig. 7. Portion of the menstrual uterus from a female examined on day 4 post coitum. This animal had a developing corpus luteum, but no regressing corpora lutea, and carried an oviductal, eight-cell embryo. Masson's trichrome, $\times[41$.

blastocysts, higher mitotic activity was observed in portions of the endometrial stroma undergoing decidual reactions (Rasweiler, 1979a).

In contrast to the oviductal epithelium of Carollia (Bonilla \& Rasweiler, 1974), the uterine glandular epithelium exhibited only modest histological changes that might be associated with secretory activity during early pregnancy. Between days $7-16$ p.c., cytoplasmic vacuolation became evident in some of the glandular epithelial cells (Fig. 9). This was variable in extent and observed only in 15 of 25 pregnant bats examined. It was reminiscent of vacuolation, due to the accumulation of glycogen, which has been noted in the endometrial glandular epithelial cells of some primates (Bartelmez et al., 1951; Witt, 1963; MacLennan \& Wynn, 1971); the cause in Carollia has not been determined.

Sixteen nonpregnant bats were examined between days 14 and 18 p.c. Most (11 of 16) had recently formed corpora lutea and thick endometria $(500-950 \mu \mathrm{m})$, although in one premenstrual female the endometrium was more compact $(400-450 \mu \mathrm{m})$. Another female in this group was in the early stages of menstruation. There was some uncertainty about when these bats had ovulated, because the females occasionally copulated when not in a periovulatory condition.

Fig. 8. (a) Uterus from a female examined on day 15 post coitum. This animal had a welldeveloped corpus luteum (shown in Fig. 6) and carried an oviductal, zona-free blastocyst. Haematoxylin and eosin, $\times 21$. (b) Higher power view of the endometrium. Masson's trichrome, $\times 141$. 
(a)

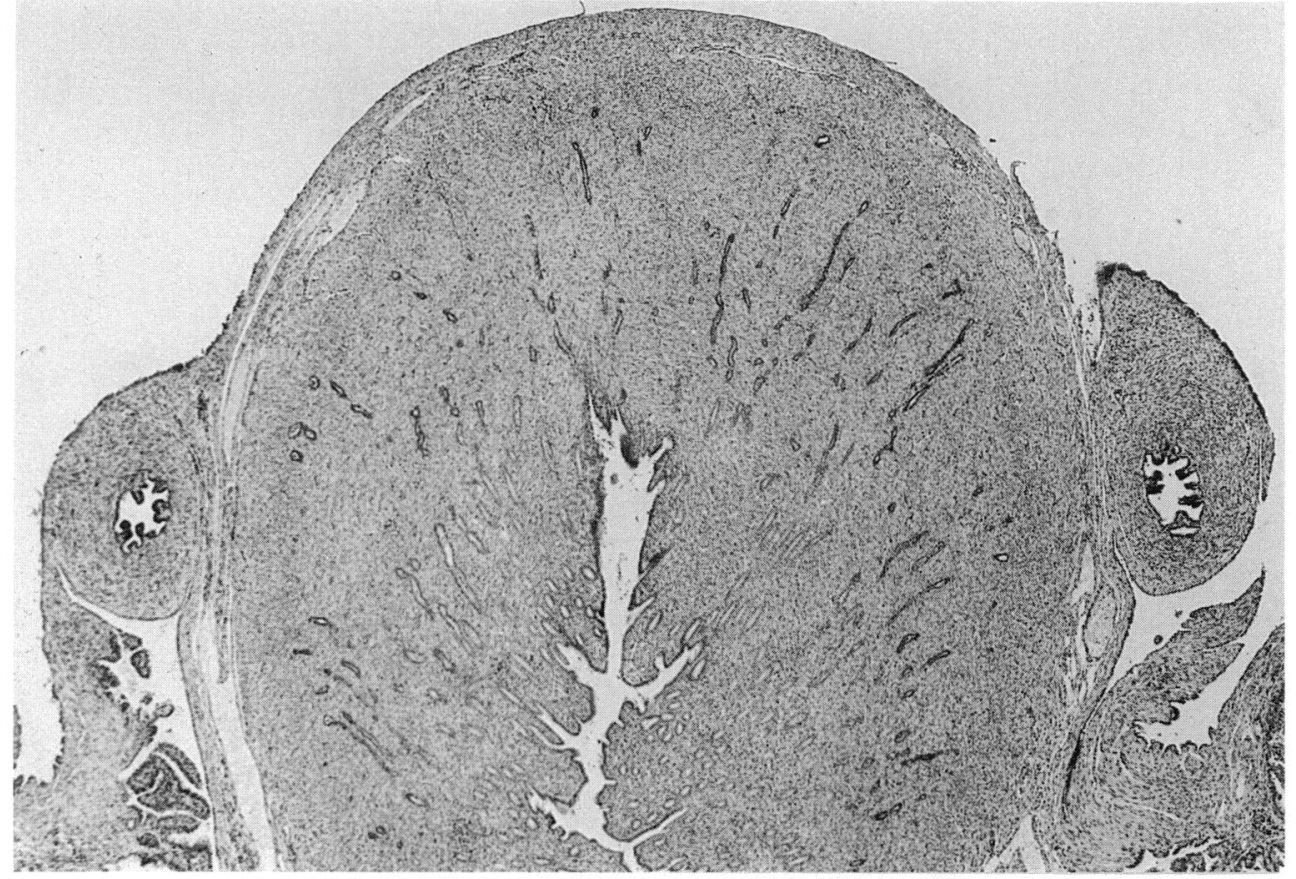

(b)

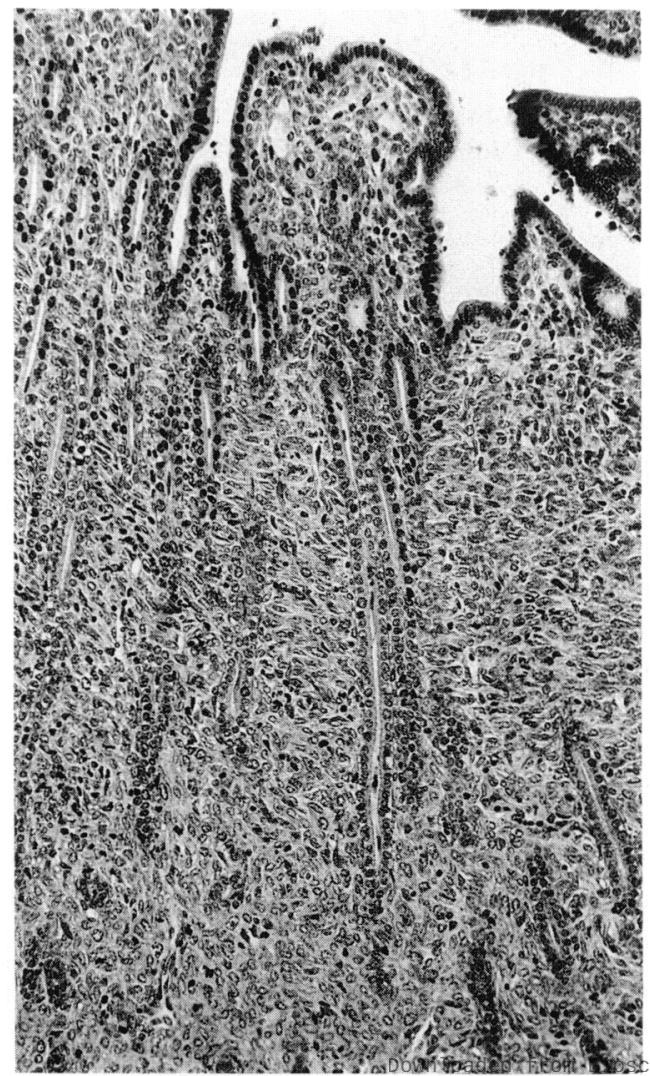




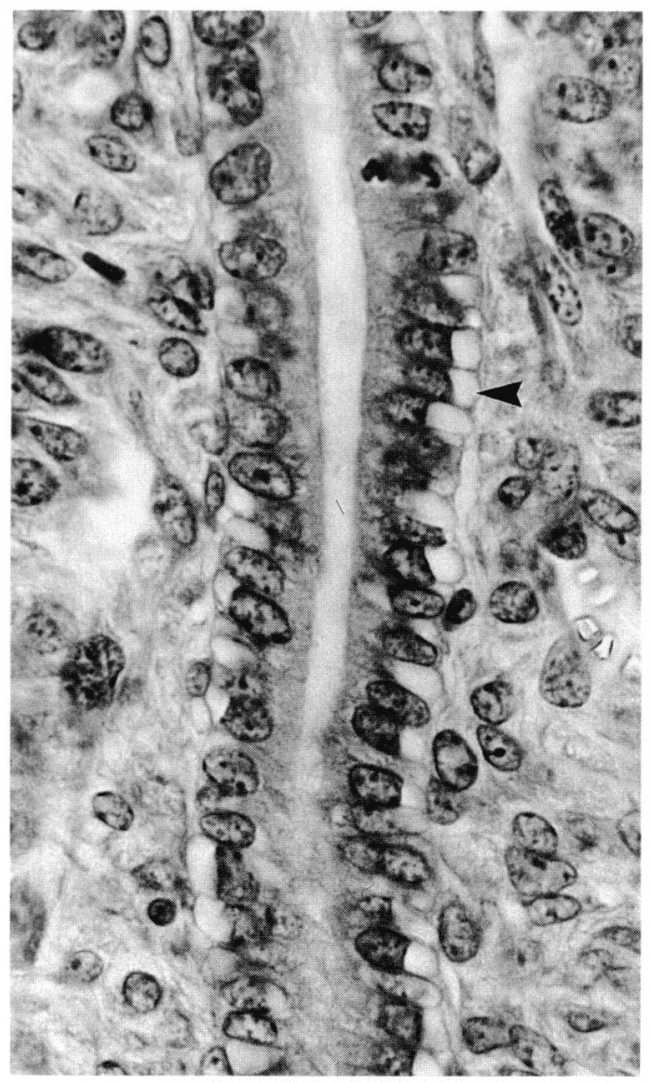

Fig. 9. Portion of a uterine gland observed in a female on day 7 post coitum. This animal carried an oviductal, 15-cell morula. Vacuoles (e.g. at arrowhead) are evident in many of the epithelial cells. Haematoxylin and Giemsa, $\times 828$.

\section{Endometrial vascularization}

Because of the role that endometrial spiral arterioles have been thought, by some, to play in the mechanism of menstruation in catarrhine primates (Markee, 1940, 1950; Shaw \& Roche, 1980), a comment on the vascularization of the endometrium in Carollia is warranted. In the specimens examined, the endometrium was vascularized for the most part by capillaries; arterioles containing a single layer of smooth muscle fibers were observed only in the deep lamina basalis. Even late in the endometrial cycle (i.e. during the onset of menstruation), no vessels similar to the spiral arterioles of catarrhine primates (Kaiser, 1947a) were observed. At this time, many of the arteriolar capillaries in the endometrium of Carollia ran a relatively straight course.

\section{Uterine granulocytes}

All the uteri examined in this study contained cells characterized by hyperchromatic nuclei and small, round acidophilic granules (Fig. 10). These were most abundant in the endometrial stroma, but also occurred in the myometrium. Similar cells have been observed in the uteri of the closely related G. soricina (Rasweiler, 1970, 1979b); however, the granulocytes in Carollia generally contained many fewer granules, and the granules were often more difficult to see because of their frequent position close to the cell nuclei. Quantitative studies on the abundance of these cells and their content of granules in various reproductive states have not yet been carried out. 


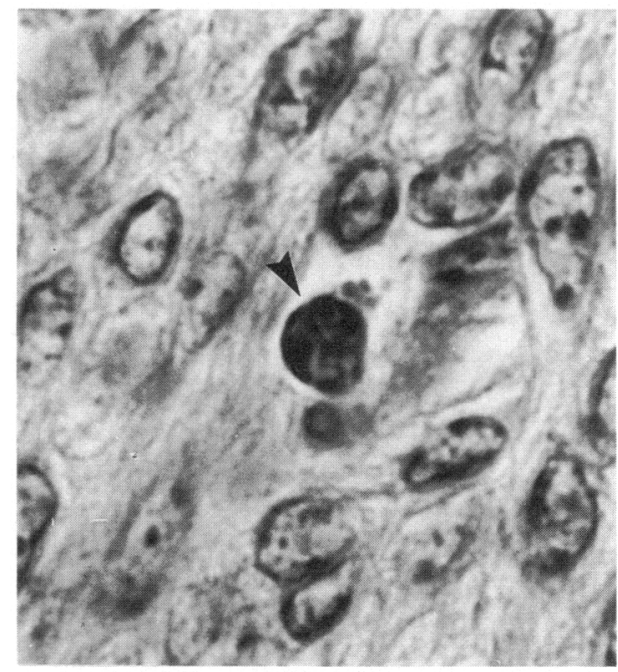

Fig. 10. Uterine granulocyte (arrowhead) in the endometrium of a female that carried an early implanting blastocyst (Day 18 post coitum). Masson's trichrome, $\times 1948$.

\section{Spontaneous ovulation}

As noted previously, many of the menstruating females had regressing corpora lutea and thick endometria. Since most of these animals were examined shortly after the initiation of copulations (Table 2), the regressing corpora lutea must have been formed as a result of earlier spontaneous ovulations. The thickness of endometrium in many of these animals also suggests that functional corpora lutea had been formed in the absence of mating activity.

\section{Discussion}

This study has established that the endometrial condition of periovulatory short-tailed fruit bats can vary considerably depending upon whether the animals have experienced a nonpregnant cycle. In females lacking regressing corpora lutea, the endometrium was shallow and proliferative. In animals having such corpora lutea, the endometrium was usually thicker, but portions of the superficial lamina functionalis were necrotic and being sloughed off with associated bleeding. This unusual relationship between menstruation and ovulation in Carollia brings to mind the prooestrous bleeding (pseudomenstruation) of dogs (Anderson \& Simpson, 1973) and the postoestrous (metoestrous) bleeding of cattle (Weber et al., 1948; Hansel \& Asdell, 1952; Weeth \& Herman, 1952). In Carollia, however, menstruation was clearly a degenerative process, usually associated with the presence of a regressing corpus luteum. It seems likely that, under such circumstances, the process is induced by the withdrawal of luteal hormonal support.

A close temporal relationship between ovulation and menstruation has also been noted in the long-tongued bat (G. soricina) and the vampire bat (Desmodus rotundus) (Rasweiler, 1970, 1974, 1979b; Quintero \& Rasweiler, 1973, 1974). Like Carollia, both these species belong to the chiropteran family Phyllostomidae. Menstruation in the elephant shrew (Elephantulus myurus) apparently is followed soon by ovulation (van der Horst \& Gillman, 1941); while Conaway \& Sorenson (1966) reported that a menstrual process occurs in the tree shrew (Tupaia longipes) a few days after a post-pseudopregnancy oestrus. In the black mastiff bat (Molossus ater; family Molossidae), a period of endometrial proliferation is usually interposed between menstruation and ovulation, as in anthropoid primates. Since phyllostomid and molossid bats are not very closely 
Table 2. Breeding records of menstruating short-tailed fruit bats with regressing corpora lutea

\begin{tabular}{ccclc}
\hline $\begin{array}{c}\text { Days housed } \\
\text { with males }\end{array}$ & $\begin{array}{c}\text { Days of } \\
\text { sperm-positive } \\
\text { smears }^{\mathrm{a}}\end{array}$ & $\begin{array}{c}\text { Day (post coitum) } \\
\text { tract was } \\
\text { examined }\end{array}$ & \multicolumn{1}{c}{ Ovarian condition } & $\begin{array}{c}\text { Endometrial } \\
\text { thickness } \\
(\mu \mathrm{m})\end{array}$ \\
\hline 14 & 1 & 1 & Large GF + regressing CL & $600-700$ \\
21 & $1,2,21$ & $21^{\mathrm{b}}$ & Large GF + regressing CL & $900-1800$ \\
1 & 1 & 1 & Recently RF + regressing CL & $550-600$ \\
17 & 1 & 1 & Large GF + regressing CL & $300-400$ \\
17 & 1 & 1 & Recently RF + regressing CL & $575-750$ \\
20 & 1,2 & 2 & Developing CL + regressing CL & $350-450$ \\
7 & 1,2 & 2 & Developing CL + regressing CL & 500 \\
11 & 1,2 & 2 & Developing CL + regressing CL & $450-550$ \\
11 & 1,2 & 2 & Developing CL + regressing CL & $400-600$ \\
18 & 1,2 & 2 & Developing CL + regressing CL & $550-650$ \\
15 & $1,4,5,9,10,11$ & $13^{\mathrm{c}}$ & Developing CL + regressing CL & $650-700$ \\
14 & $1,2,3$ & 3 & Developing CL + regressing CL & $600-700$ \\
12 & 1 & 3 & Regressing CL & $350-510$ \\
5 & $1,2,3$ & 5 & Developing CL + regressing CL & $350-500$ \\
20 & $1,6,7$ & 7 & Regressing CL & $400-430$ \\
\hline
\end{tabular}

GF, Graafian follicle; RF, ruptured follicle; $\mathrm{CL}$, corpus luteum.

${ }^{\mathrm{a}}$ Counted from the first day each female had a sperm-positive vaginal smear.

${ }^{b}$ Reclassified as Day I post coitum because of ovarian conditon.

'Reclassified as Day 3 post coitum because of ovarian condition and presence of pronuclear stage ovum in oviduct.

related and the females exhibit significant reproductive differences, there is a reasonable possibility that menstruation may have developed at least twice within the Chiroptera (Rasweiler, 1991).

Menstruation was also observed in two Carollia females that possessed regressing corpora lutea, but were not periovulatory, and in several others that lacked regressing corpora lutea. These latter findings do not necessarily mean that the withdrawal of luteal support is unimportant in the induction of menstruation in Carollia. Rather, they suggest that the phenomenon can occur under more than one set of circumstances in these bats. It is well known that anovulatory menstruation can take place in primates (Corner, 1923; Hartman, 1932; Bartelmez, 1937; Bartelmez et al., 1951).

Although it was not possible in most of the Carollia we studied to delineate the lamina functionalis sharply from the lamina basalis, the former did not appear to be shed in its entirety during menstruation. The retention of a variable amount of the lamina functionalis from one menstrual cycle to the next has also been noted in rhesus monkeys and humans (Bartelmez, 1957; McLennan \& Rydell, 1965; Flowers \& Wilborn, 1978; Nogales-Ortiz et al., 1978). Menstrual sloughing was more extensive in the black mastiff bat $(M$. ater), perhaps because endometrial differentiation seems to progress further in the non-pregnant cycle of $M$. ater than in Carollia. Molossus ater spontaneously develops decidual reactions that spread throughout the lamina functionalis and these even involve the formation of some early decidual giant cells (Rasweiler, 1991). Although the endometrium clearly becomes much thicker in Carollia as the cycle progresses, it remains unclear whether the stromal cells develop any of the characteristics of decidual cells.

Because of the unusual timing of uterine events in Carollia, spermatozoa must traverse a menstrual uterus in females that have just completed a nonpregnant cycle to fertilize the oocyte. This may not be much different from the conditions existing in the uteri of a range of mammals (including Carollia; Rasweiler \& Bonilla, 1972) that experience an oestrus soon after parturition.

Since the endometrium of Carollia was either quite shallow or menstrual at the time of ovulation, much of its growth in preparation for implantation occurred during the postovulatory period. In contrast to the patterns exhibited by humans and rhesus monkeys (Noyes et al., 1950; Bartelmez et al., 1951; Bensley, 1951; Ferenczy et al., 1979; Tabibzadeh, 1990), substantial mitotic activity persisted well into the luteal phase in the endometrial glands and stroma of Carollia. 
For much of the period of endometrial regeneration the ovum or embryo was held in the oviduct (i.e. for about 13 to possibly as long as 16 days) and it progressed to the zona-free blastocyst stage there. During approximately the first 7-8 days of this interval, the oviductal secretory cells had an unusual, highly vacuolated appearance (Bonilla \& Rasweiler, 1974). This was much more pronounced than the vacuolation of the uterine glandular epithelial cells observed in some Carollia. The cause of the oviductal vacuolation in this bat has not been established, but similar cells in related species ( $G$. soricina and Noctilio albiventris) have been found to be engorged with glycogen (Rasweiler, 1972, 1977b and unpublished observations). In all these bats, the oviduct appears to have assumed much greater responsibility for maintaining the preimplantation embryo than in most other mammals.

Because of studies involving intraocular endometrial transplants in rhesus monkeys (Markee, 1940,1950 ), increased coiling and vasoconstriction of the spiral arterioles that supply the lamina functionalis have been thought by some to play a central role in the mechanism of menstruation in catarrhine primates (Shaw \& Roche, 1980). However, several investigators have questioned the possible importance of arteriolar coiling in bringing about menstruation (Bartelmez, 1956; Hisaw \& Hisaw, 1961). It was previously reported that platyrrhine monkeys menstruate, but lack spiral arterioles in their endometria (Goodman \& Wislocki, 1935; Dempsey, 1939; Hamlett, 1939; Kaiser, 1947b). This is also the case in Carollia and the closely related phyllostomid bat, G. soricina (Rasweiler, 1970, 1979b). The endometrium of the menstruating molossid bat, $M$. ater, does possess spiral arterioles; however, increased coiling of these vessels was not observed as menstruation approached (Rasweiler, 1991). Possibly the common factor leading to menstruation in all of these species is circulatory deprivation due to changes in the contractility of smooth muscle fibres in the uterine arterioles, occurring in response to the withdrawal of ovarian steroids. This may also involve nonsteroidal vasoactive factors (Cameron et al., 1991; Davenport et al., 1991). Stromal cell density increases late in the cycle in the endometrium of humans, rhesus monkeys, $G$. soricina and Carollia. This probably indicates reduced capillary hydrostatic pressure (Bartelmez, 1937; Markee, 1940; Bartelmez et al., 1951; Prill, 1963; Witt, 1963; Rasweiler, 1970).

The occurrence of menstruation has now been well documented in catarrhine and platyrrhine primates, elephant shrews and phyllostomid and molossid bats (Hamlett, 1934; van der Horst \& Gillman, 1941; Eckstein \& Zuckerman, 1956; Rasweiler, 1979b, 1991). All these species usually bear only one or two young and exhibit advanced endometrial growth and differentiation during the nonpregnant cycle. In at least some of the catarrhine primates, the elephant shrew and $M$. ater, the endometrium develops predecidual, or even true decidual, cells in the absence of an embryo. The biological significance of menstruation may be that it permits females to eliminate such endometria rapidly in the event of fertilization failures or early embryonic losses. This may, in turn, give the seasonal breeders another opportunity to establish a pregnancy and to bear young within the same breeding season, an obvious advantage to species with low reproductive potentials. Carollia perspicillata normally produces one young, after a gestation period of about 4 months (Kleiman \& Davis, 1979) and breeds seasonally (Fleming et al., 1972, Willig, 1985; Fleming, 1988).

Menstruation would presumably have the same adaptive significance for seasonally breeding anthropoid primates and elephant shrews (van der Horst, 1955; Lancaster \& Lee, 1965), which also possess low reproductive potentials. It is more difficult to discern the advantage of menstruation to humans. Modern-day women do not exhibit discrete mating and birth seasons, although annual reproductive rhythms are clearly evident in the birth statistics for large human populations (see Roenneberg \& Aschoff, 1990a, b). Women now have long reproductive life spans and can potentially produce many children. It has been difficult, therefore, to envisage clearly the significance of shortening the human reproductive cycle by menstruation (Finn, 1987; Rasweiler, 1991). Menstruation in women may be a primitive reproductive characteristic retained from ancestors which bred more seasonally.

There is evidence that follicular development in Carollia continues during early pregnancy and it is possible that this may facilitate the prompt release of another egg in the event of early 
embryonic loss. Several females carrying embryos at the primitive streak stage had two corpora lutea of different ages, both of which were formed during the pregnancy. In one case, the more recent corpora lutea had apparently developed from the luteinization of an unruptured follicle (since it contained an entrapped ovum), but, in another bat, ovulation and conception had occurred again during a pre-existing pregnancy (Bonilla \& Rasweiler, 1974). Follicular development may occur during early pregnancy in an emballonurid bat, Peropteryx kappleri, for similar reasons (Rasweiler, 1982).

The question remains as to why the endometrium exhibits relatively advanced development during the cycle in menstruating species. Finn (1987) suggested that this may be related to problems associated with an invasive form of implantation, as exemplified by the interstitially implanting human blastocyst. Implantation in menstruating species (e.g. anthropoid primates, phyllostomid and molossid bats and elephant shrews) ranges from central to interstitial (Luckett, 1974; Wimsatt, 1975; Rasweiler, 1979a, 1991). All these animals do, however, possess invasive trophoblast and eventually form haemochorial placentas. This suggests that some of the endometrial changes evident during their reproductive cycles may be related to the development of mechanisms for controlling and/or limiting trophoblastic growth in the event of pregnancy.

Finally, it is of interest that Carollia also resembles some of the anthropoid primates and other menstruating bats in possessing a distinctive population of uterine granulocytes characterized by hyperchromatic nuclei and acidophilic cytoplasmic granules (Cardell et al., 1969; Kazzaz, 1972; Dallenbach-Hellweg, 1975; Rasweiler, 1979b, 1991). These are present during the nonpregnant cycle and early pregnancy. Recent studies in humans have established that such cells are granulated lymphocytes, but their exact functions remain unclear (Bulmer et al., 1987; King \& Loke, 1990).

Part of this research was carried out while the authors were associated with the Departamento de Morfologia, Universidad del Valle (J. J. Rasweiler IV and H. de Bonilla) and the Tulane University-Universidad del Valle International Center for Medical Research (J. J. Rasweiler IV) in Cali, Colombia. It was supported by a postdoctoral fellowship from the Population Council, and research grants from the Oficina de Investigaciones, Universidad del Valle, and the National Institutes of Health (No. AI-10050).

\section{References}

Anderson, A.C. \& Simpson, M.E. (1973) The Ovary and Reproductive Cycle of the Dog (Beagle). Geron-X, Inc., Los Altos, California.

Bartelmez, G.W. (1937) Menstruation. Physiological Reviews 17, 28-72.

Bartelmez, G. W. (1956) Premenstrual and menstrual ischemia and the myth of endometrial arteriovenous anastomoses. American Journal of Anatomy 98, 69-84.

Bartelmez, G.W. (1957) The phases of the menstrual cycle and their interpretation in terms of the pregnancy cycle. American Journal of Obstetrics and Gynecology 74, 931-955.

Bartelmez, G.W., Corner, G.W. \& Hartman, C.G. (195I) Cyclic changes in the endometrium of the rhesus monkey (Macaca mulatta). Contributions to Embryology Carnegie Institute 34, 99-144.

Bensley, C.M. (1951) Cyclic fluctuations in the rate of epithelial mitosis in the endometrium of the rhesus monkey. Contributions to Embryology Carnegie Institute 34, 87-98.

Bonilla, H. de \& Rasweiler, J.J., IV (1974) Breeding activity, preimplantation development, and oviduct histology of the short-tailed fruit bat, Carollia, in captivity. Anatomical Record 179, 385-404.
Bulmer, J.N., Hollings, D. \& Ritson, A. (1987) Immunocylochemical evidence that endometrial stromal granulocytes are granulated lymphocytes. Journal of Pathology 153, 281-288.

Cameron, I.T., Davenport, A.P., Brown, M.J. \& Smith, S.K. (1991) Endothelin-1 stimulates prostaglandin $\mathbf{F}_{2 \alpha}$ release from human endometrium. Prostaglandins, Leukotrienes and Essential Fatty Acids 42, 155-157.

Cardell, R.R., Jr, Hisaw, F.L. \& Dawson, A.B. (1969) The fine structure of granular cells in the uterine endometrium of the rhesus monkey (Macaca mulatta) with a discussion of the possible function of these cells in relaxin secretion. American Journal of Anatomy 124, 307-340.

Conaway, C.H. \& Sorenson, M.W. (1966) Reproduction in tree shrews. In Comparative Biology of Reproduction in Mammals, pp. 471-492. Ed. I. W. Rowlands. Academic Press, London.

Corner, G.W. (1923) Ovulation and menstruation in Macacus rhesus. Contributions to Embryology Carnegie Institute 15, 73-101.

Dallenbach-Hellweg, G. (1975) Histopathology of the Endometrium 2nd edn. Springer-Verlag, New York.

Davenport, A.P., Cameron, I.T., Smith, S.K. \& Brown, M.J. (1991) Binding sites for iodinated endothelin-1, 
endothelin-2 and endothelin-3 demonstrated on human uterine glandular epithelial cells by quantitative high-resolution autoradiography. Journal of Endocrinology 129, 149-154.

Dempsey, E.W. (1939) The reproductive cycle of New World monkeys. American Journal of Anatomy 64, 381-405.

Eckstein, P. \& Zuckerman, S. (1956) Changes in the accessory reproductive organs of the non-pregnant female. In Marshall's Physiology of Reproduction, Vol. I, Part I, (3rd Edn) pp. 543-654. Ed. A. S. Parkes. Longmans, Green \& Co., London.

Ferenczy, A., Bertrand, G. \& Gelfand, M.M. (1979) Proliferation kinetics of human endometrium during the normal menstrual cycle. American Journal of Obstetrics and Gynecology 133, 859-867.

Finn, C.A. (1987) Why do women and some other primates menstruate? Perspectives in Biology and Medicine 30, 566-574.

Fleming, T.H. (1988) The Short-tailed Fruit Bat. University of Chicago Press, Chicago.

Fleming, T.H., Hooper, E.T. \& Wilson, D.E. (1972) Three Central American bat communities: structure, reproductive cycles, and movement patterns. Ecology 53, 555-569.

Flowers, C.E., Jr \& Wilborn, W.H. (1978) New observations on the physiology of menstruation. Obstetrics and Gynecology 51, 16-24.

Gardner, A.L. (1977) Feeding habits. In Biology of Bats of the New' World Family Phyllostomatidae, Part II, pp. 293-350. Eds R. J. Baker, J. K. Jones, Jr \& D. C. Carter. Texas Tech Press, Lubbock, Texas.

Goodman, L. \& Wislocki, G.B. (1935) Cyclical uterine bleeding in a New World monkey (Ateles geoffroyi). Anatomical Record 61, 379-387.

Hamlett, G.W.D. (1934) Uterine bleeding in a bat (Glossophaga soricina). Anatomical Record 60, 9-17.

Hamlett, G.W.D. (1935) Notes on the embryology of a phyllostomid bat. American Journal of Anatomy 56, 327-353.

Hamlett, G.W.D. (1939) Reproduction in American monkeys. I. Estrous cycle, ovulation and menstruation in Cebus. Anatomical Record 73, 171-187.

Handley, C.O., Jr (1976) Mammals of the Smithsonian Venezuelan Project. Brigham Young University Science Bulletin, Biology Series 20 (5), 1-91.

Hansel, W. \& Asdell, S.A. (1952) The causes of bovine metestrous bleeding. Journal of Animal Science 11, 346-354.

Hartman, C.G. (1932) Studies in the reproduction of the monkey Macaca (Pithecus) rhesus, with special reference to menstruation and pregnancy. Contributions to Embryology Carnegie Institute 23, 1-161.

Hisaw, F.L. \& Hisaw, F.L., Jr (1961) Action of estrogen and progesterone on the reproductive tract of lower primates. In Sex and Internal Secretions, 3rd edn, Vol. 1, pp. 556-589. Ed. W. C. Young. Williams \& Wilkins, Baltimore.

Kaiser, I. (1947a) Histological appearance of coiled arterioles in the endometrium of rhesus monkey, baboon, chimpanzee and gibbon. Anatomical Record 99, 199-225.

Kaiser, I. (1947b) Absence of coiled arterioles in the endometrium of menstruating New World monkeys. Anatomical Record 99, 353-367.
Kazzaz, B.A. (1972) Specific endometrial granular cells. A semiquantitative study. European Journal of Obstetrics and Gynaecology 3, 77-84.

King, A. \& Loke, Y.W. (1990) Uterine large granular lymphocytes: a possible role in embryonic implantation? American Journal of Obstetrics and Gynecology 162, 308-310.

Kleiman, D.G. \& Davis, T.M. (1979) Ontogeny and maternal care. In Biology of Bats of the New World Family Phyllostomatidae, Part III, pp. 387-402. Eds R. J. Baker, J. K. Jones, Jr \& D. C. Carter. Texas Tech Press, Lubbock, Texas.

Lancaster, J.B. \& Lee, R.B. (1965) The annual reproductive cycle in monkeys and apes. In Primate Behavior. Field Studies of Monkeys and Apes, pp. 486-513. Ed. I. DeVore. Holt, Rinehart and Winston, New York.

Luckett, W.P. (1974) Comparative development and evolution of the placenta in primates. In Contributions to Primatology, Vol. 3, pp. 142-234. Ed. W. P. Luckett, S. Karger, Basel.

MacLennan, A.H. \& Wynn, R.M. (1971) Menstrual cycle of the baboon. I. Clinical features, vaginal cytology and endometrial histology. Obstetrics and Gyneco$\log y$ 38, $350-358$.

McLennan, C.E. \& Rydell, A.H. (1965) Extent of endometrial shedding during normal menstruation. Obstetrics and Gynecology 26, 605-621.

Markee, J.E. (1940) Menstruation in intraocular endometrial transplants in the rhesus monkey. Contributions to Embryology Carnegie Institute 28, 219-308.

Markee, J.E. (1950) The morphological and endocrine basis for menstrual bleeding. Progress in Gynecology 2, 63-74

Mossman, H.W. (1937) Comparative morphogenesis of the fetal membranes and accessory uterine structures. Contributions to Embryology Carnegie Institute 26, 129-246.

Mossman, H.W. (1987) Vertebrate Fetal Membranes. Rutgers University Press, New Brunswick, New Jersey.

Nogales-Ortiz, F., Puerta, J. \& Nogales, F.F., Jr (1978) The normal menstrual cycle. Chronology and mechanism of endometrial desquamation. Obstetrics and Gynecology 51, 259-264.

Noyes, R.W., Hertig, A.T. \& Rock, J. (1950) Dating the endometrial biopsy. Fertility and Sterility 1, 3-25.

Pine, R.H. (1972) The Bats of the Genus Carollia. Technical Monograph 8. Texas A and M University Press, College Station, Texas.

Prill, H.J. (1963) Circulation. In The Normal Human Endometrium, pp. 227-247. Ed. H. SchmidtMatthiesen. McGraw-Hill, New York.

Quintero, H.F. \& Rasweiler, J.J., IV (1973) The reproductive biology of the female vampire bat, Desmodus rotundus. American Zoologist 13, 1284.

Quintero, H.F. \& Rasweiler, J.J., IV (1974) Ovulation and early embryonic development in the captive vampire bat, Desmodus rotundus. Journal of Reproduction and Fertility 41, 265-273.

Rasweiler, J.J., IV (1970) The laboratory biology of the long-tongued bat, Glossophaga soricina: maintenance procedures, estivation, the menstrual cycle, histophysiology of the oviduct and intramural 
implantation. PhD Thesis, Cornell University, Ithaca, New York.

Rasweiler, J.J., IV (1972) Reproduction in the longtongued bat, Glossophaga soricina. I. Preimplantation development and histology of the oviduct. Journal of Reproduction and Fertility 31, 249-262.

Rasweiler, J.J., IV (1974) Reproduction in the longtongued bat, Glossophaga soricina. II. Implantation and early embryonic development. American Journal of Anatomy 139, 1-36.

Rasweiler, J.J., IV (1977a) Preimplantation development, fate of the zona pellucida, and observations on the glycogen-rich oviduct of the little bulldog bat, Noctilio albiventris. American Journal of Anatomy 150, 269-300.

Rasweiler, J.J., IV (1977b) The care and management of bats as laboratory animals. In Biology of Bats, Vol. III, pp. 519-617. Ed. W. A. Wimsatt. Academic Press, New York.

Rasweiler, J.J., IV (1979a) Bats as models in studies on folliculogenesis, menstruation, early pregnancy, and sperm survival. In Animal Models for Research on Contraception and Fertility, pp. 437-446. Ed. N. J. Alexander. Harper and Row, Hagerstown, Maryland.

Rasweiler, J.J., IV (1979b) Early embryonic development and implantation in bats. Journal of Reproduction and Fertility 56, 403-416.

Rasweiler, J.J., IV (1982) The contribution of observations on early pregnancy in the little sac-winged bat, Peropteryx kappleri, to an understanding of the evolution of reproductive mechanisms in monovular bats. Biology of Reproduction 27, 681-702.

Rasweiler, J.J., IV (1987) Prolonged receptivity to the male and the fate of spermatozoa in the female black mastiff bat, Molossus ater. Journal of Reproduction and Ferility 79, 643-654.

Rasweiler, J.J., IV (1991) Spontaneous decidual reactions and menstruation in the black mastiff bat, Molossus ater. American Journal of Anatomy 191, 1-22.

Rasweiler, J.J., IV \& Bonilla, H. de (1972) Laboratory maintenance methods for some nectarivorous and frugivorous phyllostomatid bats. Laboratory Animal Science 22, 658-663.
Roenneberg, T. \& Aschoff, J. (1990a) Annual rhythm of human reproduction: I. Biology, sociology, or both? Journal of Biological Rhythms 5, 195-216.

Roenneberg, T. \& Aschoff, J. (1990b) Annual rhythm of human reproduction: II. Environmental correlations. Journal of Biological Rhythms 5, 217-239.

Sazima, I. (1976) Observations on the feeding habits of phyllostomatid bats (Carollia, Anoura, and Vampyrops) in southeastern Brazil. Journal of Mammology 57, 381-382.

Shaw, S.T., Jr \& Roche, P.C. (1980) Menstruation. In Oxford Review of Reproductive Biology, Vol. 2, pp. 41-96. Ed. C. A. Finn. Oxford University Press, Oxford.

Tabibzadeh, S. (1990) Proliferative activity of lymphoid cells in human endometrium throughout the menstrual cycle. Journal of Clinical Endocrinology and Metabolism 70, 437-443.

van der Horst, C.J. (1955) Elephantulus going into anoestrus; menstruation and abortion. Philosophical Transactions of the Royal Society of London, Series B: Biological Science 238, 27-61.

van der Horst, C.J. \& Gillman, J. (1941) The menstrual cycle in Elephantulus. South African Journal of Science 6, 27-47.

Weber, A.F., Morgan, B.B. \& McNutt, S.H. (1948) A histological study of metrorrhagia in the virgin heifer. American Journal of Anatomy 83, 309-327.

Weeth, H. \& Herman, H. (1952) A histological and histochemical study of the bovine oviducts, uterus and placenta. Research Bulletin of Missouri Agricultural Experimental Station 501, 1-54.

Willig, M.R. (1985) Reproductive patterns of bats from Caatingas and Cerrado Biomes in northeast Brazil. Journal of Mammalogy 66, 668-681.

Wimsatt, W.A. (1975) Some comparative aspects of implantation. Biology of Reproduction 12, 1-40.

Witt, H.-J. (1963) Structural elements and general function of the endometrium. In The Normal Human Endometrium, pp. 24-64. Ed. H. Schmidt-Matthiesen. McGraw-Hill, New York.

Received 5 March 1991 